\title{
The study of sport manager's decision making styles who are working in Center and Rural Organizations of General Directorate of Sport
}

\author{
Mustafa VURAL ${ }^{1}$, Hakan Salim CAGLAYAN² \\ ${ }^{1}$ Institute of Education Sciences, Sakarya University, Sakarya, Turkey. \\ 2 School of Physical Education and Sports, Department of Sports Management, Selcuk University, Konya, Turkey. \\ This study is a part of Mustafa Vural's master thesis. \\ Address correspondence to Mustafa Vural,mustafaavurall@gmail.com
}

\begin{abstract}
The present study is conducted in order to determine the effect of demographic variables on decision making styles of sport managers who are working in center and rural organizations of general directorate of sport. A descriptive survey model oriented method is used within the research in order to reveal the present situation. The study group is composed of 170 sport managers working in center and rural organizations of general directorate of sport (Provincial Director of Youth Services and Sport = 32/ Departmental Manager =138). "Melbourne Decision Making Questionaire" which was developed by Mann et al. (1998) and then adapted by Deniz (2004) to Turkish is used as data collection tool along with "Self-Information Form". While analyzing the data, Mann-Whitney U Test for paired comparison and Kruskal-Wallis Variance Analysis for multiple comparisons are used. In multiple comparisons when Kruskal Wallis Variance Analyses results were found meaningful, Mann Whitney $U$ Test is applied to find out which groups were the sources of the meaningful differences. The significance level in the present study is $\alpha=0.05$. As a result of the study it is found that in terms of gender, age, educational level and managerial status self-esteem has no significant effect on decision making styles of sport managers; however, there was a significant difference regarding professional seniority and managerial seniority variables. It is also seen that there were no significant differences in all the sub-dimensions of decision making scale of sport managers considering the whole demographic variables.

Keywords: Self-esteem in decision making, decision making styles, sport manager.
\end{abstract}

\section{INTRODUCTION}

"It is no doubt that managers are the ones who has the most part and responsibility in all institutions and organizations. Also in sport institutions and organizations it is the manager who is responsible for carrying out the services and activities by the determined objectives" (12). Sport manager is the person who "loves sport and sportsman, has social leadership characteristics, open to innovation and development, not falling behind the changes and development, has all the qualities of a modern manager, giving service fondly, intentionally, deliberately and devotedly"(13).

"Managers decide during the process of fulfilling their responsibilities and tasks with the intention of being successful. While they are awarded for their prosperous decisions, they may be criticized for the unprosperous ones. In an effective management, deciding on a sustainable success is a must during the decision making process as it is the most important criterion" (14). "Through all these managerial responsibilities, the ability of manage and lead can only be developed via effective decision making as the decisions form the basis of the acts" (23). Management "both start with a decision and ends with a decision" (9).

With its most general meaning, decision making is "the process of picking one way from various ways which is supposed to take the individual reaches his or her goal" (18). "Decision making is taken and defined in many different perspectives but still couldn't get a common definition with opinion-unity". The common characteristics of the definitions regarding decisionmaking are as in the following: "Being active is deciding on the act itself; the thing affecting the act is all kind of decision; the process of deciding depending on the evaluations; the process of choosing the effective one from all the alternatives including various acts to reach the goal; the process of problem solving; come to a decision by making 
comments about the information or comparing them related to the problem" (18).

"The process of giving decisions at a high quality is the first concern of organizational anxiety and it is especially related with the way that the manager runs the decision making process" (21). "One of the most important results of the researches conducted in the field of management and a decision making act is that the decision making is the heart of the process. All the other qualities of the management process are connected to decision making; giving a decision is manager's judgment in order to solve the problem. As a reliable and dynamic person, the top manager of the organization is the person who ensures decision making and motivates the organization in line with the decisions. Although decision making is a process that takes manager's time, a good manager is also considered as a person giving effective decisions (9).

Ministry of Youth and Sport, and General Directorate of Sport which is connected to it, are the only institutions managing the sport in our country so they bear tremendous responsibility in development of sport. In this respect, the determination of decision making styles of sport managers who are working in center and rural organizations of general directorate of sport considered important as they have tremendous responsibility in developing the sport.

Related literature in the field has many studies regarding manager's decision making styles working in different units (1, 2, 4, 15, 24, 30). However, there were no studies regarding sport managers' decision making styles. In the light of the information gathered from the literature; the present study is conducted to examine the decision making styles of the sport managers in Turkey who are working in center and rural organizations of Youth Services and in Provincial Directorate of Sport and seen as authority in sport management. In this way, the decision making styles of the sport managers and the effect of demographic variables on these styles were examined.

\section{MATERIAL \& METHOD}

\section{Study Model}

A descriptive survey model oriented method is used within the research in order to reveal the present situation.

\section{Population and Sample}

The study population is composed of 408 sport managers working in center and rural organizations of General Directorate of Sport (Youth Services and General Manager of Sport $=81 /$ Departmental Manager $=327$ ). In order to collect reliable data, the method of sampling was not applied and the study was conducted on general population. The "population sampling itself" (8) was taken as the study population in the present study.

In the study, it was tried to apply the survey to all sport managers, however; the study was limited with those sport managers working in 43 provincial and central organizations due to the fact that there were managers who were unwilling to participate in the survey and that there were absent managers as the study was conducted. As it stands, 170 sport managers in total were included in the study (Provincial Director of Youth Services and Sport $=32$ / Departmental Manager =138).

\section{Data Collection Tools}

"Melbourne Decision Making Questionaire" which was developed by Mann et al. (19) and then adapted by Deniz (11) to Turkish is used in the study as data collection tool along with "SelfInformation Form."

\section{Melbourne Decision Making Questionaire (MDMQI-II)}

Melbourne Decision Making Questionaire was developed by Mann et al. (19), in order to compare self-esteem in decision making and decision making styles of university students in a cross -cultural study involving six countries. It is a scale consisting of two parts. The scale was adapted by Deniz (11) to Turkish in order to specify decision making styles of Turkish university students and conduct comparative studies with the students of other countries (11).

Melbourne Decision Making Questionaire consists of two parts:

I. Part: This part aims to self-esteem (selfassurance) in decision making. It consists of 6 articles and one sub-factor.

II. Part: As to this part, it is a scale consisting of 22 articles and four sub-factors aiming to determine decision making styles. These are;

1. Vigilance Decision Making Style: It refers to the state of an individual looking for the required information vigilance before making a 
decision and making selection after evaluating the alternatives vigilance.

2. Buckpassing Decision Making Style: It refers to the state of an individual buckpassing making a decision, having a tendency to leave the decisions to others and thus trying to get rid of responsibility by assigning liability to others.

3. Procrastination Decision Making Style: It refers to the state of an individual who delays, postpones and retards a decision without a valid reason.

4. Hypervigilance Decision Making Style: It refers to the state of an individual trying to reach immediate solutions by displaying hasty behaviours as a result of feeling under time pressure when he encounters a decision making condition (11).

In both parts, there are 3-likert type (True, Slightly True, and Not True) answering options. Validity and reliability studies of Melbourne Decision Making Questionaire (MDMQI-II) were performed on second grade students of Selcuk University, Technical Training Faculty, Department of Computer Systems and Automotive Teaching in 2002-2003 academic year and data from 154 students were gathered (11). Internal consistency coefficients for MSMS I-II, applied to 154 university students, were calculated as Cronbach Alpha $=.72$ for self-esteem in decision making; .80 for vigilance decision making which is a sub-dimension of decision-making; .78 for buckpassing decision making; .65 for procrastination decision making and.71 for hypervigilance decision making (11).

\section{Data Analysis}

In order to determine whether the difference between group averages for demographic variables is significant or not, it was initially tested during data analysis phase with Kolmogorov-Smirnov test and Shapiro-Wilk test whether self-esteem levels of sport managers in decision making and subdimensions of scale of decision making styles present a normal distribution or not. In such analysis, results were significant for all variables. That is to say, it was observed that all variables did not present a normal distribution. This is why, independent variables regarding sub-problems, levels of self-esteem in decision making and decision making styles were tested with nonparametric tests.

Mann-Whitney U Test for paired comparison and Kruskal-Wallis Variance Analysis for multiple comparisons were used. In multiple comparisons when Kruskal Wallis Variance Analyses results were found significant, Mann Whitney U Test is applied to determine which groups were the sources of such difference. Obtained data were analyzed on SPSS (Statistical Package For Social Scientists for Windows Release 18.0) programmed on the computer and significance level was tested at a level of 0.05 .

\section{RESULTS}

$16.5 \%$ of sport managers took part in the study was women and $83.5 \%$ of such were males. While the age group between 41-50 years constituted the highest rate with $42.9 \%$ percent, the age group of 61 years and over constituted the smallest rate with $5.3 \%$ percent when managers were surveyed based on their age groups. While the university graduate group constituted the highest rate with $69.4 \%$ percent; it was the group of high-school graduates that constituted the smallest educational group with $4.7 \%$ percent when managers were reviewed based on educational levels. It was found out that sport managers have a professional seniority of at most 26 years and over $(31.8 \%)$ and their professional seniority for management was between 1-5 years at most (36.5\%). Consequently, it was determined that $81.2 \%$ of sport managers took part in the study carry out their duty in the position of departmental managers, whereas $18.8 \%$ work as Provincial Directorate of Youth Services and Sport.

The results in Table 1 indicate that self-esteem of sport managers in decision making ( $U=1937.50$; $\mathrm{P}>0.05)$, and sub-dimensions of vigilance decision making ( $\mathrm{U}=1797.00 ; \mathrm{P}>0.05)$, buckpassing decision making ( $\mathrm{U}=1923.00$; $\mathrm{P}>0.05)$, procrastination decision making ( $\mathrm{U}=1793.50 ; \mathrm{P}>0.05)$ and hypervigilance decision making ( $\mathrm{U}=1924.00$; $\mathrm{P}>0.05)$ which are subdimensions of decision making scale had no significant difference with respect to gender variable.

Results in Table 2 indicate that self-esteem of sport managers in decision making $\left[\mathrm{X}^{2}(4)=0.770\right.$; $\mathrm{P}>0.05]$; vigilance decision making style $\left[\mathrm{X}^{2}(4)=2.103\right.$; $\mathrm{P}>0.05]$, buckpassing decision making style $\left[\mathrm{X}^{2}(4)=\right.$ 5.232; $P>0.05]$, procrastination decision making style $\left[\mathrm{X}^{2}(4)=0.681 ; \mathrm{P}>0.05\right]$ and hypervigilance decision making style $\left[\mathrm{X}^{2}(4)=5.019 ; \mathrm{P}>0.05\right]$ which are subdimensions of decision making scale had no significant difference regarding gender variable.

Results in Table 3 indicate that self-esteem of sport managers in decision making $\left[\mathrm{X}^{2}(3)=1.087\right.$; $P>0.05]$, vigilance decision making style $\left[\mathrm{X}^{2}(3)=0.379\right.$; $\mathrm{P}>0.05]$, buckpassing decision making style 
$\left[\mathrm{X}^{2}(3)=1.409 ; \mathrm{P}>0.05\right]$, procrastination decision making style $\left[X^{2}(3)=5.603 ; \quad P>0.05\right]$ and hypervigilance decision making style $\left[\mathrm{X}^{2}(3)=1.154 ; \mathrm{P}>0.05\right]$ which are sub-dimensions of decision making scale had no significant difference according to educational level variable.

Results in Table 4 indicate that vigilance decision making style $\left[X 2_{(5)}=5.910 ; \quad P>0.05\right]$, buckpassing decision making style $\left[\mathrm{X}^{2}(5)=4.264\right.$;
$\mathrm{P}>0.05]$, procrastination decision making style $\left[\mathrm{X}^{2}(5)=\right.$ 8.010; $\mathrm{P}>0.05]$ and hypervigilance decision making style $\left[\mathrm{X}^{2}(5)=9.116\right.$; $\left.\mathrm{P}>0.05\right]$ of sport managers which are sub-dimensions of decision making scale had no significant difference according to professional seniority variable whereas self-esteem style $\left[\mathrm{X}^{2}(5)=\right.$ 13.584; $\mathrm{P}<0.05$ ] of sport managers in decision making had a significant difference with respect to professional seniority variable.

Table 1. Mann-Whitney U Test results indicating the comparison of dimensions of decision making scale and self-esteem in decision making based on genders of sport managers.

\begin{tabular}{|c|c|c|c|c|c|c|c|}
\hline & & \multicolumn{2}{|c|}{ Female $(\mathrm{n}=28)$} & \multicolumn{2}{|c|}{ Male $(n=142)$} & \multirow{2}{*}{$\mathrm{U}$} & \multirow{2}{*}{$\mathrm{P}$} \\
\hline & & Mean Rank & Sum of Ranks & Mean Rank & Sum of Ranks & & \\
\hline \multirow[t]{2}{*}{ Decision self-esteem } & & 83.70 & 2343.50 & 85.86 & 12191.50 & 1937.50 & 0.830 \\
\hline & Vigilance & 78.68 & 2203.00 & 86.85 & 12332.00 & 1797.00 & 0.417 \\
\hline Sub-dimensions of & Buckpassing & 87.82 & 2459.00 & 85.04 & 12076.00 & 1923.00 & 0.782 \\
\hline \multirow[t]{2}{*}{ Decision Making Scale } & Procrastination & 92.45 & 2588.50 & 84.13 & 11946.50 & 1793.50 & 0.408 \\
\hline & Hypervigilance & 87.79 & 2458.00 & 85.05 & 12077.00 & 1924.00 & 0.786 \\
\hline
\end{tabular}

Table 2. Kruskal Wallis-H Test results indicating the comparison of dimensions of decision making scale and self-esteem in decision making based on ages of sport managers.

\begin{tabular}{|c|c|c|c|c|c|c|c|c|c|}
\hline & & $\begin{array}{c}30 \text { years and } \\
\text { younger }(n=15)\end{array}$ & $\begin{array}{c}\text { 31-40 years- } \\
\text { old }(n=37)\end{array}$ & $\begin{array}{c}41-50 \text { years- } \\
\text { old }(n=73)\end{array}$ & $\begin{array}{c}\text { 51-60 years- } \\
\text { old }(n=36)\end{array}$ & $\begin{array}{c}61 \text { years-old } \\
\text { and over }(n=9)\end{array}$ & df & $X^{2}$ & $\mathrm{P}$ \\
\hline & & Mean Rank & Mean Rank & Mean Rank & Mean Rank & Mean Rank & & & \\
\hline \multirow[t]{2}{*}{ Decision self-esteem } & & 86.33 & 85.64 & 85.88 & 87.63 & 72.00 & 4 & 0.770 & 0.942 \\
\hline & Vigilance & 98.23 & 89.72 & 80.53 & 86.50 & 83.22 & 4 & 2.103 & 0.717 \\
\hline Sub-dimensions of & Buckpassing & 107.20 & 79.86 & 81.95 & 84.75 & 104.33 & 4 & 5.232 & 0.264 \\
\hline \multirow[t]{2}{*}{ Decision Making Scale } & Procrastination & 85.73 & 87.01 & 82.52 & 90.35 & 83.67 & 4 & 0.681 & 0.954 \\
\hline & Hypervigilance & 98.63 & 91.12 & 83.66 & 73.58 & 103.11 & 4 & 5.019 & 0.285 \\
\hline
\end{tabular}

Table 3. Kruskal Wallis-H Test results indicating the comparison of dimensions of decision making scale and self-esteem in decision making based on educational levels of sport managers.

\begin{tabular}{|c|c|c|c|c|c|c|c|c|}
\hline & & $\begin{array}{l}\text { High School } \\
(\mathrm{n}=8)\end{array}$ & $\begin{array}{c}\text { Academy for } 2 \\
\text { years }(n=33)\end{array}$ & $\begin{array}{l}\text { University } \\
(\mathrm{n}=118)\end{array}$ & $\begin{array}{l}\text { Postgraduate } \\
(\mathrm{n}=11)\end{array}$ & $\mathrm{df}$ & $X^{2}$ & $\mathrm{P}$ \\
\hline & & Mean Rank & Mean Rank & Mean Rank & Mean Rank & & & \\
\hline \multicolumn{2}{|l|}{ Decision self-esteem } & 94.56 & 91.36 & 83.85 & 79.00 & 3 & 1.087 & 0.780 \\
\hline \multirow{4}{*}{$\begin{array}{l}\text { Sub-dimensions of } \\
\text { Decision Making } \\
\text { Scale }\end{array}$} & Vigilance & 87.88 & 83.20 & 86.63 & 78.59 & 3 & 0.379 & 0.945 \\
\hline & Buckpassing & 96.31 & 85.38 & 83.56 & 98.82 & 3 & 1.409 & 0.704 \\
\hline & Procrastination & 60.25 & 73.29 & 90.72 & 84.55 & 3 & 5.603 & 0.133 \\
\hline & Hypervigilance & 89.50 & 79.45 & 87.72 & 76.86 & 3 & 1.154 & 0.764 \\
\hline
\end{tabular}

Table 4. Kruskal Wallis-H Test results indicating the comparison of dimensions of decision making scale and self-esteem in decision making based on professional seniority of sport managers.

\begin{tabular}{|c|c|c|c|c|c|c|c|c|c|}
\hline $\begin{array}{l}\text { (A) } 1-5 \text { years } \\
(n=29)\end{array}$ & $\begin{array}{l}\text { (B) } 6-10 \\
\text { years } \\
(n=13)\end{array}$ & $\begin{array}{c}(C) 11-15 \\
\text { years }(n=31)\end{array}$ & $\begin{array}{c}\text { (D) } 16-20 \\
\text { years } \\
(n=15)\end{array}$ & $\begin{array}{c}(\mathrm{E}) \\
21-25 \text { years } \\
(n=28)\end{array}$ & $\begin{array}{c}(\mathrm{F}) 26 \text { years }+ \\
(\mathrm{n}=54)\end{array}$ & $\mathrm{df}$ & $X^{2}$ & $\mathrm{P}$ & $\begin{array}{l}\text { Significant } \\
\text { Difference }\end{array}$ \\
\hline Mean Rank & Mean Rank & Mean Rank & Mean Rank & Mean Rank & Mean Rank & & & & \\
\hline
\end{tabular}

\begin{tabular}{|c|c|c|c|c|c|c|c|c|c|c|c|}
\hline Decision self-esteem & & 70.81 & 88.08 & 64.73 & 104.90 & 93.46 & 95.18 & 5 & 13.584 & $0.018^{*}$ & $\begin{array}{l}\text { A-D, A-F, } \\
\text { C-D, C-E }\end{array}$ \\
\hline \multirow{4}{*}{$\begin{array}{l}\text { Sub-dimensions of } \\
\text { Decision Making } \\
\text { Scale }\end{array}$} & Vigilance & 76.43 & 77.35 & 74.18 & 101.80 & 91.64 & 91.12 & 5 & 5.910 & 0.315 & - \\
\hline & Buckpassing & 96.10 & 98.00 & 89.74 & 78.40 & 76.07 & 81.22 & 5 & 4.264 & 0.512 & - \\
\hline & Procrastination & 93.34 & 101.31 & 86.63 & 99.40 & 88.50 & 71.42 & 5 & 8.010 & 0.156 & - \\
\hline & Hypervigilance & 96.79 & 103.58 & 89.94 & 99.00 & 77.59 & 72.89 & 5 & 9.116 & 0.105 & - \\
\hline
\end{tabular}


Table 5. Kruskal Wallis-H Test results indicating the comparison of dimensions of decision making scale and self-esteem in decision making based on managerial seniority of sport managers.

\begin{tabular}{|c|c|c|c|c|c|c|c|c|c|c|c|}
\hline & & $\begin{array}{c}\text { (A) } 1-5 \text { years } \\
(n=62)\end{array}$ & $\begin{array}{c}\text { (B) } 6-10 \\
\text { years }(n=30)\end{array}$ & $\begin{array}{c}(\mathrm{C}) 11-15 \\
\text { years }(\mathrm{n}=40) \\
\end{array}$ & $\begin{array}{c}(D) 16-20 \\
\text { years }(n=13)\end{array}$ & $\begin{array}{c}(E) 21-25 \\
\text { years }(n=12)\end{array}$ & $\begin{array}{l}\text { (F) } 26 \text { years } \\
+(n=13)\end{array}$ & \multirow[t]{2}{*}{ df } & \multirow[t]{2}{*}{$X^{2}$} & \multirow[t]{2}{*}{$\mathrm{P}$} & \multirow{2}{*}{$\begin{array}{l}\text { Significant } \\
\text { Difference }\end{array}$} \\
\hline & & Mean Rank & Mean Rank & Mean Rank & Mean Rank & Mean Rank & Mean Rank & & & & \\
\hline Decision self-esteem & & 82.10 & 66.27 & 98.30 & 76.85 & 90.58 & 95.18 & 5 & 11.771 & $0.038^{*}$ & $\begin{array}{l}\text { B-C, } \\
\text { B-F }\end{array}$ \\
\hline \multirow{4}{*}{$\begin{array}{l}\text { Sub-dimensions of } \\
\text { Decision Making } \\
\text { Scale }\end{array}$} & Vigilance & 86.75 & 70.57 & 100.35 & 90.85 & 71.33 & 76.04 & 5 & 8.270 & 0.142 & - \\
\hline & Buckpassing & 83.34 & 91.43 & 94.76 & 85.12 & 70.00 & 68.31 & 5 & 4.865 & 0.433 & - \\
\hline & Procrastination & 83.68 & 88.45 & 95.30 & 81.27 & 72.75 & 73.23 & 5 & 3.575 & 0.612 & - \\
\hline & Hypervigilance & 91.05 & 85.98 & 84.34 & 80.92 & 69.00 & 81.31 & 5 & 2.418 & 0.789 & - \\
\hline
\end{tabular}

${ }^{*} \mathrm{P}<0.05$

Table 6. Mann-Whitney U Test results indicating the comparison of dimensions of decision making scale and self-esteem in decision making based on managerial status of sport managers.

\begin{tabular}{|c|c|c|c|c|c|c|c|}
\hline & & \multicolumn{2}{|c|}{$\begin{array}{l}\text { Provincial Directorate of Youth } \\
\text { Services and Sport }(n=32)\end{array}$} & \multicolumn{2}{|c|}{$\begin{array}{l}\text { Departmental Manager } \\
\qquad(\mathrm{n}=138)\end{array}$} & \multirow[t]{2}{*}{$\mathrm{U}$} & \multirow[t]{2}{*}{$\mathrm{P}$} \\
\hline & & Mean Rank & Sum of Ranks & Mean Rank & Sum of Ranks & & \\
\hline \multirow[t]{2}{*}{ Decision self-esteem } & & 95.73 & 3063.50 & 83.13 & 11471.50 & 1880.50 & 0.187 \\
\hline & Vigilance & 88.91 & 2845.00 & 84.71 & 11690.00 & 2099.00 & 0.660 \\
\hline Sub-dimensions of Decision & Buckpassing & 80.28 & 2569.00 & 86.71 & 11966.00 & 2041.00 & 0.500 \\
\hline \multirow[t]{2}{*}{ Making Scale } & Procrastination & 86.33 & 2762.50 & 85.31 & 11772.50 & 2181.50 & 0.915 \\
\hline & Hypervigilance & 81.28 & 2601.00 & 86.48 & 11934.00 & 2073.00 & 0.587 \\
\hline
\end{tabular}

Results in Table 5 indicate that vigilance decision making style $\left[\mathrm{X}^{2}(5)=8.270 ; \quad \mathrm{P}>0.05\right]$, buckpassing decision making style $\left[\mathrm{X}^{2}(5)=4.865\right.$; $\mathrm{P}>0.05]$, procrastination decision making style $\left[\mathrm{X}^{2}(5)=\right.$ $3.575 \mathrm{P}>0.05]$ and hypervigilance decision making style $\left[\mathrm{X}^{2}(5)=2.418 ; \mathrm{P}>0.05\right]$ of sport managers which are sub-dimensions of decision making scale had no significant difference according to managerial seniority variable, whereas self-esteem style $\left[\mathrm{X}^{2}(5)=\right.$ 11.771; $\mathrm{P}<0.05$ ] of sport managers in decision making had a significant difference regarding managerial seniority variable.

The results in Table 6 indicate that self-esteem of sport managers in decision making ( $\mathrm{U}=1880.50$; $\mathrm{P}>0.05)$; and sub-dimensions of vigilance decision making ( $\mathrm{U}=2099.00 ; \mathrm{P}>0.05)$, buckpassing decision making ( $\mathrm{U}=2041.00 ; \mathrm{P}>0.05)$, procrastination decision making ( $\mathrm{U}=2181.50 ; \mathrm{P}>0.05)$ and hypervigilance decision making ( $\mathrm{U}=2073.00$; $\mathrm{P}>0.05)$ which are subdimensions of decision making scale had no significant difference according to status variable.

\section{DISCUSSION}

Following conclusions are reached in the study conducted in order to determine the effect of demographic variables on decision making styles of sport managers who are working in centre and rural organizations of General Directorate of Sport:
It was determined that all sub-dimensions (vigilance, buckpassing, procrastination and hypervigilance) of decision making scale and selfesteem of sport managers in decision making who participated in the survey had no significant difference pursuant to gender variable (Table 1). However; examining the Table, it was observed that male directors had a higher point average in terms of self-esteem in decision making and vigilance decision making, compared to that of female directors; whereas female directors had a higher point average in terms of buckpassing, procrastination and hypervigilance decision making, compared to that of male directors. This situation may stem from the fact that duties and responsibilities in traditional Turkish family structure are assigned to male children in earlier ages than female children and that men are more successful than women regarding the issue of decision making accordingly.

Similar conclusions were obtained also in the studies, conducted with different study groups in the related literature in the field, which generally support our findings. It was determined in a study conducted by Altay (1) that there were no significant differences in decision making styles of managers based on gender variable; In the study conducted by Temur (30), it was confirmed that there was no significance in terms of statistics in other sub- 
dimensions other than buckpassing decision making point averages in the examination of subdimensions of decision making with regard to gender variable; in the study conducted by Taşçı (26) to determine the perceptions with respect to effects of primary school teachers in decision making process of school directors, it was made firm that other sub-dimensions of decision making scale apart from sub-dimension of director's decision making had no difference according to gender variable. Once again, in other studies conducted by Taşdelen (27), Köse (17), Kesici, (16), Deniz (10), Sinangil (25), Avşaroğlu (3), Çetin (7), Çetin et al. (6), it was established that there was no significant difference between self-esteem in decision making and decision making styles of participants based on gender variable.

As to the studies conducted abroad, different conclusions were reached. In the study conducted on Dutch adolescents by Tuinstra et al. (31), while sub-dimension of self-reliance in decision making was high in favour of males; sub dimensions of hypervigilance, buckpassing decision making and acting without thought were high in favour of females. In his study conducted for American and Taiwanese students, Mau (20) stated that self-esteem in decision making and decision making styles of American students had no significant difference based on gender variable; whereas self-esteem in decision making and decision making styles of Taiwanese students had significant difference based on gender variable and such difference was in favour of female students. The fact that different results were obtained in the studies conducted abroad brought the effect of socio-cultural differences in decision making into the forefront. As a matter of fact, Mau (20), Man et al. (19) put forward that differences between the cultures are important elements in decision making.

It was ascertained that self-esteem of sport managers in decision making who participated in the survey and all sub-dimensions (vigilance, buckpassing, procrastination and hypervigilance) of decision making scale had no significant difference based on age variable (Table 2). In other words, that the managers take part in different age groups is not effective in determination of self-esteem in decision making and decision making styles of directors.

In the relevant literature, just as there are studies $(1,18,26)$, showing parallelism with our findings, which determine that there is no statistically significant difference between decision making styles of participants and gender variable, there are also studies $(5,15,30)$ not having parallelism with our survey findings; that is, there are studies which determine that decision making styles of participants had significant difference based on age variable It is thought that such is the result of the fact that study groups are different.

It was found out that self-esteem of sport managers in decision making who participated in the survey and all sub-dimensions (vigilance, buckpassing, procrastination and hypervigilance) of decision making scale had no significant difference based on educational level variable (Table 3). In other words, educational backgrounds of managers were not effective in determination of self-esteem in decision making and decision making styles of directors.

In relevant literature in the field, it was determined in the studies, which do not match up with our findings, that there were significant differences between decision making styles and educational levels of participants, $(1,15,28,29,30)$ which was thought to be stemming from the dissimilarity of study group.

There were no significant differences encountered in the comparison of all subdimensions (vigilance, buckpassing, procrastination and hypervigilance) of decision making scale based on professional seniority variable of sport managers participated in the survey (Table 4). That is to say, the fact that the directors work in different service years of their duty is not effective on determination of their decision making styles.

As to the comparison of directors' levels of selfesteem in decision making based on professional seniority variable, no significant difference was encountered (Table 4). Mann Whitney U-test was applied over binary comparisons of professional seniority variable in self-esteem in decision making, in order to determine from which groups the significant difference observed between the groups stemmed from. As a result of this application, it was found out that self-esteem of the directors with a professional seniority between 1-5 years in decision making was significantly low compared to that of directors with a professional seniority between 16-20 years and 26 years and over; and that self-esteem of the directors with a professional seniority between 11-15 years in decision making was significantly low, compared to that of directors with a professional seniority between 16-20 years and 21-25 years. Based on this finding; it is possible for us to 
say that those directors with a lower professional seniority had a lower self-assurance level in decision making phase compared to that of directors who have longer working periods than themselves in terms of professional seniority.

In the relevant literature regarding the studies that support our survey findings $(28,30)$; it was detected that there was a significant relationship between decision making styles and professional seniorities of the participants.

There was no significant difference encountered in the comparison of all sub-dimensions (vigilance, buckpassing, procrastination and hypervigilance) of decision making scale based on the managerial seniority variable of sport managers participated in the survey (Table 5). In other words, that the managers have different managerial seniorities is not effective in determination of decision making styles of directors.

As to comparison of self-esteem levels of directors in decision making based on variable for managerial seniority, there was no significant difference encountered (Table 5). Mann Whitney Utest was applied over binary comparisons of variable of managerial seniority in self-esteem in decision making, in order to determine from which groups the significant difference observed between the groups stemmed from. As a result of this application, it was found out that self-esteem of the directors with a managerial seniority between 6-10 years in decision making was significantly low compared to that of directors with a managerial seniority of 11-15 years and 26 years and over; based on this finding; it is possible for us to say that those directors with a lower managerial seniority had a lower self-assurance level in decision making phase compared to that of directors having higher managerial seniority.

Exercising of self-esteem in low levels in decision making was much associated with aspects such as people's having lower life satisfaction and experiencing negative feeling situations such as loneliness, depression and sensitiveness; whereas exercising of self-esteem in high levels was much associated with aspects such as people's having high life satisfaction, achieving academic success, high levels of familial acceptance, being internally controlled and having confidence in himself $(22,32)$. Considering the findings of study, the reason why sport managers, who are more experienced in terms of managerial study, have high levels of self-esteem in decision making can be attributed to the fact that they trust themselves, they are relaxed since they have worked for long years as a director in their duty and they have achieved successes.

In the study, theme of which is the effect of emotional intelligence levels of directors to decision making styles thereof, conducted by Altay (1) which has parallelism with our survey findings, it was determined that there was a statistically significant difference between the managerial status of directors in the company where they work and rational decision making style which is one of decision making styles; but there was no significant difference between non-rational, dependant, buckpassing and immediate decision making styles.

There were no significant differences in the comparison of self-esteem of sport managers participated in the survey in decision making and all sub-dimensions (vigilance, buckpassing, procrastination and hypervigilance) of decision making scale based on the variable of managerial status (Table 6). In other words, that the managers hold office as provincial directors of youth services and sport or as departmental managers is not effective in determination of self-esteem in decision making or decision making styles of directors.

As a conclusion; it can be said that self-esteem in decision making and all sub-dimensions of decision making scale of managers took part in the study had no statistically significant difference based on gender, age, educational level and managerial status variable.

Further, It can be said that self-esteem of sport managers in decision making had a statistically significant difference pursuant to professional seniority variable and such difference stemmed from the fact that the managers with a professional seniority of 1-5 years have a lower level of selfesteem in decision making compared to that of managers with a professional seniority of 16-20 years and 26 years and over; and that the managers with a professional seniority of 11-15 years have a lower level of self-esteem in decision making compared to that of managers with a professional seniority of 16-20 years and 21-25 years; as to subdimensions of decision making scale, it can be said that there is no statistically significant difference regarding professional seniority variable.

Additionally, It can be said that self-esteem of sport managers in decision making had a statistically significant difference pursuant to managerial seniority variable and such difference stemmed from the fact that the managers with a 
professional seniority of 6-10 years have a lower level of self-esteem in decision making compared to that of managers with a professional seniority of 1115 years and 26 years and over; as to all subdimensions of decision making scale, it can be said that there is no statistically significant difference regarding managerial seniority variable.

Considering the results of the survey, following proposals may be suggested:

It should be ensured to organize in-service training programmers in order that sport managers learn decision making process, decision making phases, decision making models and decision making techniques and that self-confidence of sport managers is increased during decision making phase; it is thought thanks to such training programmers that self-confidence of especially those managers who have lower working periods and managerial seniorities will be increased during decision making phase.

It is further thought that the studies, in which decision making styles of sport managers working in different departments (Ministry of Youth and Sport, Independent Sport Federations, Sport Clubs etc.) are investigated, will also contribute to this field. It is also though that detailed studies in which other factors (problem solving skills, ways of overcoming stress, leadership styles, organizational loyalty, managerial styles) that effect decision making styles of sport managers, will also contribute to this field. This study was as a quantitative research; qualitative research may be conducted and the sources of reasons may be examined in detail.

\section{REFERENCES}

1. Altay U. Effects of managers? Emotional intelligence level on desicion making styles and a research. MA Thesis. Istanbul University, Institute of Social Sciences, Istanbul, Turkey, 2011.

2. Apaydin M. Influence of executive nurses management skills on their decision making and ingenuity. MA Thesis. Beykent University, Institute of Social Sciences, Istanbul, Turkey, 2011.

3. Avsaroglu S. The Study of styles of coping with stress, decision-making and self-esteem of university students on decision-making in terms of self-esteem and some variables. PhD Thesis. Selcuk University, Institute of Social Sciences, Konya, Turkey, 2007.

4. Badour M. Perceptions of organizational environment according to the hospital managers decision-making styles a field research. MA Thesis. Gazi University, Institute of Social Sciences, Ankara, Turkey, 2013.

5. Baron J, Granato L, Spranca M, Teubal E. Decision-making biases in children and early adolescents: Exploratory studies. Merrill Palmer Quarterly, 1993; 39: 23-47
6. Cetin MC, Caglayan HS, Yildırım Y. Investigation of self esteem in decision making and decision making styles of physical education and sport school special ability test participating candidates. 11 th International Sports Science Congress, Poster Presentation, November 10-12. pp. 368-369, 2010, Antalya.

7. Cetin MC. In terms of some variables the comparatively analysis of decision making styles, social skill levels, and forms of coping with stress the students of the physical education and sports school. PhD Thesis. Gazi University, Institute of Education Sciences, Ankara, Turkey, 2009.

8. Cilenti M. Educational Technology and Teaching. Ankara: Printing House, 1984.

9. Daglı A. Problem solving and decision making. Electronic Journal of Social Sciences, 2004; 3(7): 41-49.

10. Deniz ME. A Study of comparation of university students decision making strategies and social skill levels with respect to ta-dominant ego states and some self-qualities. PhD Thesis. Selcuk University, Institute of Social Sciences, Konya, Turkey, 2002.

11. Deniz ME. Investigation of the relation between decision selfesteem, decision making style and problem solving skill of the university students. Eurasian Journal of Educational Research, 2004; 4(15): 23-35.

12. Donuk B. Sport Management and Employment Areas. Istanbul: Otuken Publications, 2005: 25.

13. Germi H, Sunay H. Evaluation of problem solving skills of sport directors working in General Directorate of Youth and Sport. $9^{\text {th }}$ International Sports Science Congress, November 35. pp. 1187-1190, 2006, Mugla.

14. Harrison EF, Pelletier MA. The essence of management decision. General Review, 2000; 38(7): 462-470.

15. Ilmez M. Determine the relationship between leadership styles and making a decision styles of manager and employee in the public organization. MA Thesis. Ufuk University, Institute of Social Sciences, Ankara, Turkey, 2010.

16. Kesici S. A comparative analysis of university students decision making strategies according to psychological need pattern and personal characteristics. PhD Thesis. Selcuk University, Institute of Social Sciences, Konya, Turkey, 2002.

17. Köse A. Psychological Counseling and Guidance First Grade Students Personal Preferences and Decision Making Strategies Regarding Gender and Socioeconomic Status. MA Thesis. Hacettepe University, Institute of Social Sciences, Ankara, Turkey, 2002.

18. Kuzgun Y. Development and standardization of decision strategies scale. VII. International Psychology Congress Scientific Studies, September 22-25. pp. 161-170, 1992, Ankara.

19. Mann L, Radford M, Burnett P, Ford S, Bond M, Leung K, Nakamura H, Vaughan G, Yang KS. Cross-cultural differences in self-reported decision-making style and confidence. International Journal of Psychology, 1998; 33(5): 325-335.

20. Mau WC. Cultural differences in career decision-making styles and self efficacy. Journal of Vocational Behavior, 2000; 57: 365-378.

21. Ozmen F, Yoruk S. In the frame of human resource management, a development of an inventory related to the 
effectiveness of school principals in decision making. Firat University Journal of Social Science, 2005; 15(2): 179-198.

22. Piskin M. Comparison of Turkish and English high school students in terms of self-respect. 3. National Psychological Counselling and Guidance Congress, pp. 21-35, 1997, Cukurova University Press, Adana.

23. Rausch E. Guidelines for management and leadership decision. Management Decision, 2003; 41(10): 979-988.

24. Sevindi K. A research about the decision making level of hospital directors. MA Thesis. Beykent University, Institute of Social Sciences, Istanbul, Turkey, 2012.

25. Sinangil HK. Relationship in decision making and anxiety in Executive candidates. VII. International Psychology Congress Scientific Studies, September 22-25. pp. 171-177, 1992, Ankara.

26. Tasc1 O. Relationship between perceptions of primary school teachers regarding the effects of school directors in decision making and organizational devotedness. MA Thesis. Yeditepe University, Institute of Social Sciences, Istanbul, Turkey, 2011.

27. Tasdelen A. Decision making sytes of student teachers in relation to different psychosocial characteristics. Dokuz Eylul University, Institute of Education Sciences, Izmir, Turkey, 2002.

28. Tekin M, Tasgin O. Analysis of decision-making and thinking styles of kicboxing trainers. Turkish Kickboxing Federation Journal of Sport Science, 2009; 2(1): 11-27.

29. Tekin OA, Ehtiyar RV. Decision making in management: An investigation about decision making styles of different department managers who work in five star hotels in west Antalya region. Journal of Yasar University, 2010; 20(5): 33943414.

30. Temur OF. Effect of decision making styles of directors according to teachers' perceptions on organizational devotedness of teachers. MA Thesis. Recep Tayyip Erdogan University, Institute of Social Sciences, Rize, Turkey, 2012.

31. Tuinstra J, Sonderen FLP, Groothoff WJA, Heuvel DP. Reliability, validity and structure of the adolescent decision making questionnaire among adolescents in the Netherlands. Personality and Individual Differences, 2000; 28: 273-285.

32. Williams JM, Currie C. Self-esteem and physical development in early adolescence: Pubertal timing and body image. Journal of Early Adolescence, 2000; 20(2): 129-149. 